\title{
Identifying Tourism Attractions' Potentials of Protected Area: A Case Study in Bulue Village, Soppeng District, Indonesia
}

\author{
Eko Yuwono $^{1 *}$, Risma Illa Maulany ${ }^{2}$, Roland A. Barkey ${ }^{2}$ \\ ${ }^{1}$ Graduate School, Hasanuddin University, Makassar, Indonesia \\ ${ }^{2}$ Faculty of Forestry, Hasanuddin University, Makassar, Indonesia
}

\begin{abstract}
The purpose of this study was to identify the tourism attractions' potentials of the landscape that had the major function as protected areas. Bulue Village was selected in this study as nearly $85 \%$ of the territory lies inside the protected areas. The comprehensive spatial analysis combined with descriptive analysis was utilized as approaches toward the study. The Scenic Beauty Estimation (SBE) was also carried out to obtain the potential of nature-based tourism attractions based on tourist's perceptions. The results showed that there were nine spots of attractions that had a high value of SBE. Those attractions were identified as Lejja hot spring (SBE=81.33), Lejja view (SBE=129.33), camping ground $(S B E=51.78)$, Datae hot spring $(S B E=71.22)$, Menawoe waterfall ( $S B E=184.44)$, Lapaserengi waterfall $(\mathrm{SBE}=143.00)$, Batumurue waterfall $(\mathrm{SBE}=127.89)$, Waepuange waterfall $(\mathrm{SBE}=122.11)$, and Sarasa-tandre waterfall ( $\mathrm{SBE}=147.44)$. Only Anoa sanctuary has a moderate value. Nevertheless, there some issues that need to be considered, in particular, to prevent further forest degradation by providing economic alternatives for the locals and improving the management of the site. These findings have shown the need for finding a specific strategy to develop ecotourism activities based on the characteristics of the landscape.
\end{abstract}

Keywords: Bulue village, ecotourism in protected area, landscape-based ecotourism, scenic beauty estimation.

\section{INTRODUCTION}

Ecotourism is a component of sustainable tourism [1,2]. According to The International Ecotourism Society, ecotourism as responsible travel to natural areas maintains the welfare of the local community and involves interpretation and education [3]. The development of ecotourism has to contribute minimal impact on ecosystems and benefit to the local community's economy, as well as to respect and value the local culture/local wisdom. Ecotourism is developed using a participatory process that involves all stakeholders and is monitored to detect negative and positive impacts generated from the activities. Meanwhile, it becomes more commons that ecotourism is seen as part of a protected area's management strategy. The integration of ecotourism with protected areas creates a symbiotic relationship: ecotourism needs protected areas and protected areas need ecotourism [4].

A landscape typically consists of physical, biotic aspects, and human elements [5], which has historical and cultural dimensions [6]. The functions of landscape relate to the provision of environmental goods and services, including production functions (food, clothing, housing, energy), habitat (biodiversity), regulators (various

\footnotetext{
${ }^{*}$ Correspondence address:

Eko Yuwono

Email : yuwono.wono@gmail.com

Address : Graduate School, Hasanuddin University, Makassar, 90245
}

cycles in the biosphere, and atmosphere) and information (beauty, recreation, cultural) [7]. A landscape that functioned as a protected area has a higher vulnerability value than other forms of the area. Landscape utilization activities that ignore the value of vulnerability can harm environmental aspects (water, soil, air, flora, and fauna), cultural (decreasing local wisdom values), and the beauty of the landscape. Landscape inventory and evaluation of natural and spatial culture values recognized as an important step in the planning and development process of a landscape [6].

Bulue Village has various types of landscapes with hilly topography and different altitudes from 80 to $920 \mathrm{~m}$ above sea level [8]. As indicated in the map (Fig. 1), nearly $85 \%$ of the village's area is included as the conservation and protected forest. Only $15 \%$ of the area is utilized as cultivated areas. Furthermore, Bulue landscape is a part of Batu-batu River catchment area, which flows to Lake Tempe. Currently, the width of Lake Tempe has shrunk extensively due to massive sediment flow from the upstream eroded land in rainy seasons [9]. High erosion in the upstream area was caused by the massive conversion of protected areas into dry land cultivation areas.

There are many human settlements in Bulue Village. Most of the people have lived as farmers so that the potential of forest degradation is very large in the area and tends to increase with the growing population [10]. Forest areas that are relatively critical due to forest degradation can 
reduce the value of natural beauty so that forest management systems that are related to ecotourism are needed to create alternative income for the community. Thus, the purpose of this study is to identify the tourism attraction potential of Bulue Village, which can be used as the driving factor in developing ecotourism.

\section{MATERIAL AND METHOD}

To identify the tourism attractions' potential of Bulue Village, the approaches used were by combining spatial analysis and descriptive analysis [11]. The Scenic Beauty Estimation was also employed to describe the perceptions of the local people/visitors toward tourism attractions potential. The study was Bulue Village, Soppeng District (Fig. 1). Meanwhile, the stages of this study were presented in Figure 2, which is included preliminary studies, data collection, analysis, synthesis, and recommendations.

\section{Data Collection and Analysis}

The data in this study obtained from several sources. To build spatial analysis, the data were gained from online and offline searches via internet access and government official agencies. The primary data of the tourism attractions potential were obtained through surveys and interviews. The survey was conducted on landscape elements (land cover), which classified based on object-based image analysis from Spot 6/7 imagery, which was acquired in 2018. The assessment of land cover included a variety of scenery and the uniqueness of attractions. Data were taken in the field, including coordinates and photos of each location. Interviews were conducted with the people who live nearby the potential area. The results of the survey captured accessibility, current utilization activities, and the community livelihood.

To provide information on the perceptions of local people/visitors on the potential attractions and measure the scenic beauty estimation (SBE), a set of the questionnaire were distributed to 30 respondents. The respondents were only given a maximum of eight seconds to give value to each photo of the nature-based tourism attractions. The rating scores ranged from 1 to 10 , where a score of 1 indicates the least preferred value, and a score of 10 indicates the most preferred value. The questionnaire results analyzed by using the SBE [12]. The SBE formula is presented in Equation 1 . The data were analyzed descriptively by incorporating the results of spatial analysis and scenic beauty estimation.

$$
S B E x=(Z x-Z o) x 100
$$

Description

SBEx $=$ the estimation of the aesthetic value of $x^{\text {th }}$ photo

$Z x \quad=$ the average of $z$ value (using $z$ table) of $x^{\text {th }}$ photo

Zo $=$ the average of $z$ value (using $z$ table) of $x^{\text {th }}$ photo as a standard.

\section{RESULT AND DISCUSSION}

\section{Landscape Potentials for Tourism Attraction}

Landscape elements of Bulue Village were dominated by secondary forest $56.393 \%$ and primary forest $24.24 \%$. Another elements are rainfed field $8.917 \%$, mixed plantation $4.393 \%$, rice field $2.767 \%$, shrub $2.312 \%$, settlement $0.976 \%$, and swamp $0.003 \%$ (Fig. 3).

The nature-based tourism attractions were dominated by aquatic-based attractions, in line with the major function of the landscape as the upstream area of the Batu-Batu River, which provides flows to Lake Tempe. Lejja hot spring, Lejja view, Anoa sanctuary, camping ground, Datae hot spring, and Lapaserengi waterfall were located in Lejja Recreation Park. Meanwhile, Menawoe waterfall, Batumurue waterfall, Waepuange waterfall, and Sarasa-tandre waterfall were located in Walanae Protected Forest.

Lejja hot spring has the potential for hot spring water that smell-free of sulfur with relatively large water discharge. It has become the leading tourist destination of Soppeng District [13]. Meanwhile, other potentials have not been chosen nor utilized as tourist destination objects. Anoa sanctuary is a place to save endemic Sulawesi animals outside their natural habitat. Lejja's view is the natural scenery of the Bulue landscape. The camping ground comprised of a relatively large shrub area in Lejja Recreation Park. In general, accessibility to Lejja hot spring, Anoa sanctuary, Lejja view, and camping ground are paved road. Meanwhile, accessibility to Menawoe waterfall, Batumurue waterfall, Waepuange waterfall, Sarasa-tandre waterfall, Lapaserengi waterfall, and Datae hot spring are secondary roads and trail roads.

Besides the nature-based tourism attractions, the livelihood of Bulue's people also could attract special traveler, i.e. harvesting honey directly from the forest, and traditionally palm sugar making. The activity of observing the process of taking honey in a tree, eating a beehive containing eggs and larvae mixed with honey, could be used as a tour package, as seen in Figure 4. 

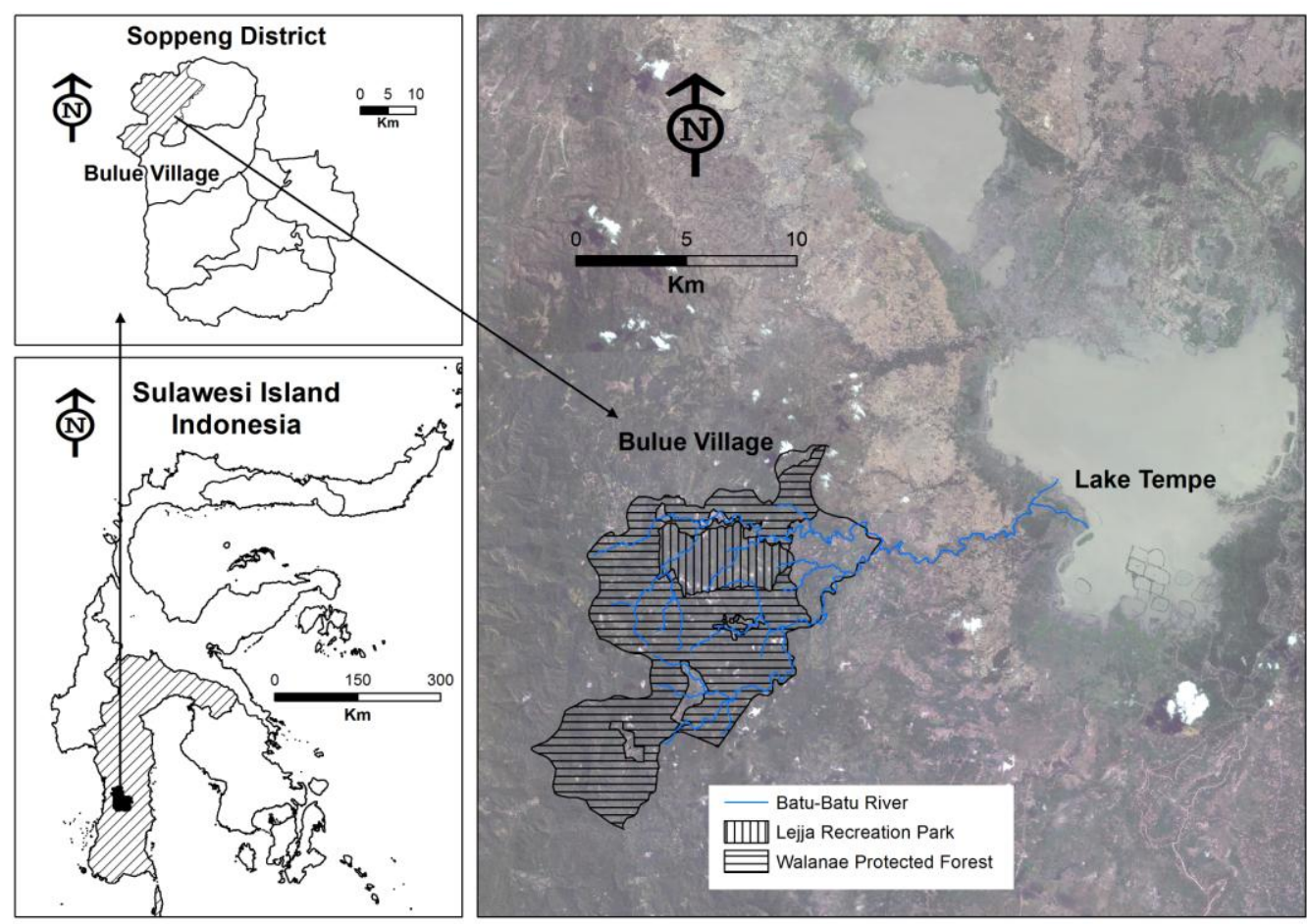

Figure 1. The geographical location of Bulue Village, Soppeng District, Indonesia

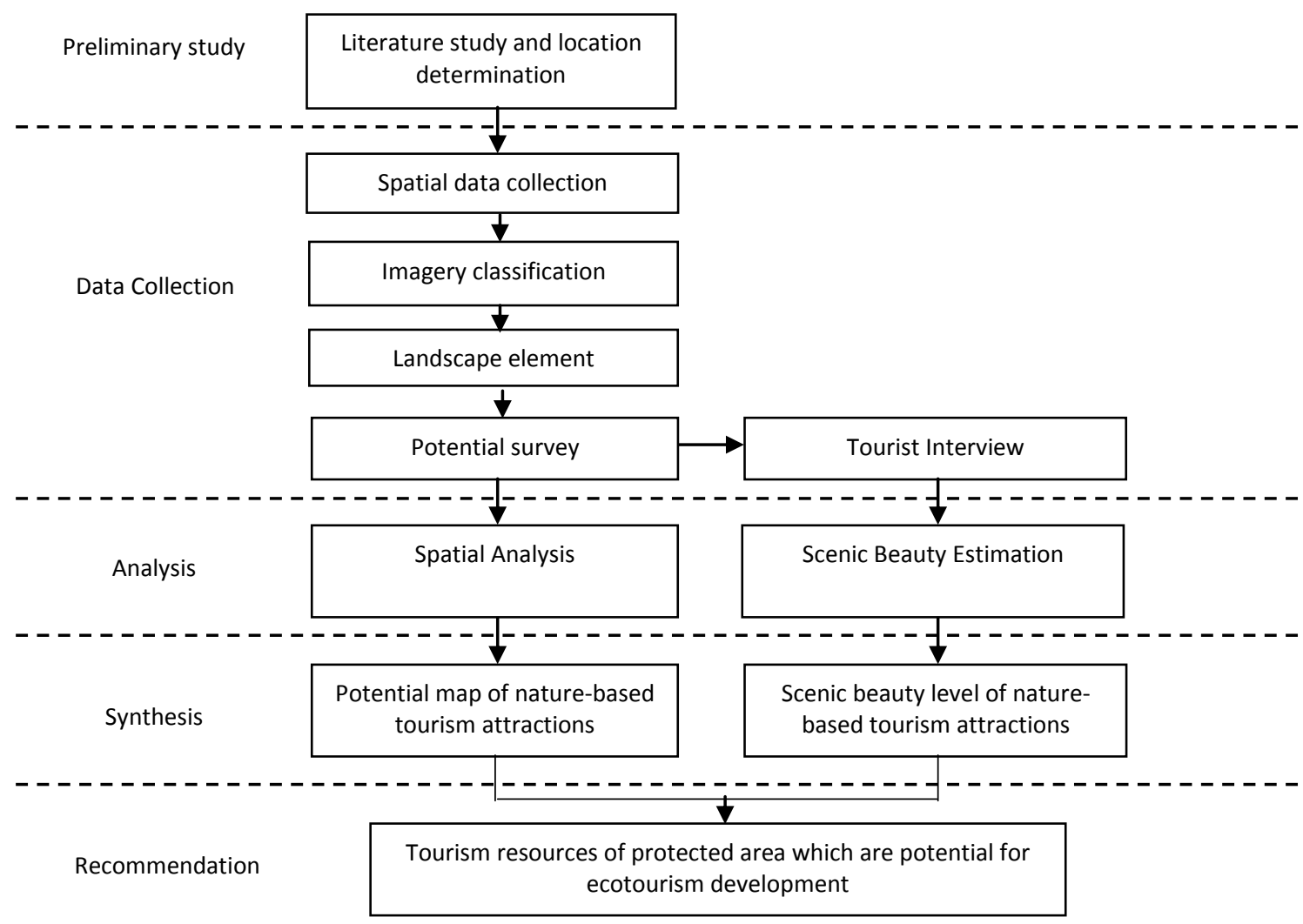

Figure 2. Phases of Study Process 


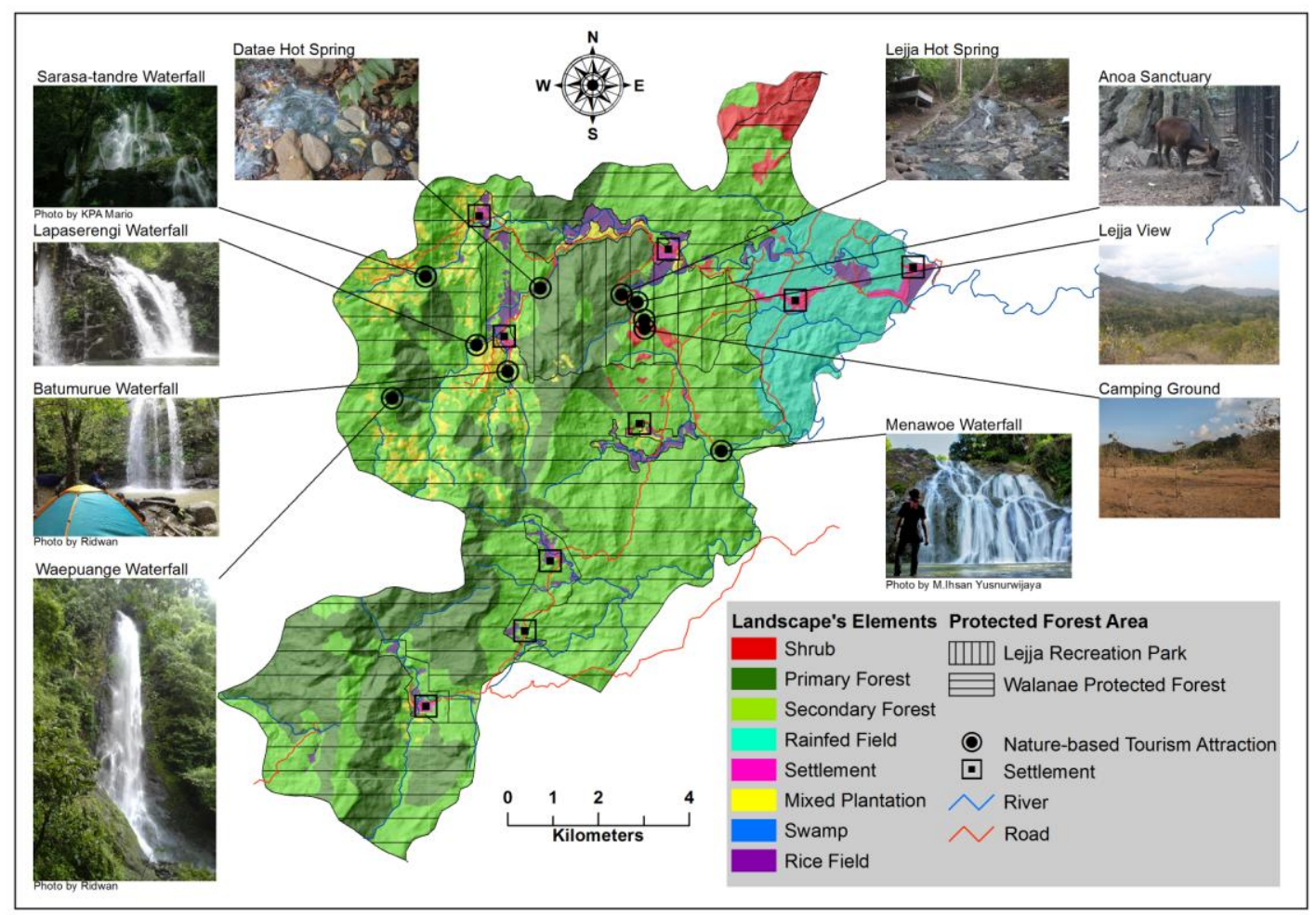

Figure 3. The nature-based tourism attractions of Bulue village, Soppeng district, Indonesia

Table 1.1 Scenic beauty estimation value of the nature-based tourism attractions of Bulue Village, Soppeng district, Indonesia (SBE= Scenic Beauty Estimation) (* High SBE score: > 20; Moderate:-20 <SBE score > 20; Low SBE score <-20)

\begin{tabular}{|c|c|c|c|c|}
\hline No & $\begin{array}{l}\text { Nature-based } \\
\text { tourism attractions }\end{array}$ & Descriptions & $\begin{array}{c}\text { SBE } \\
\text { Score }\end{array}$ & $\begin{array}{l}\text { Scenic Beauty } \\
\text { Value * }\end{array}$ \\
\hline 1 & Lejja hot spring & $\begin{array}{l}\text { Smell-free sulfur of hot spring water sources used by } \\
\text { visitors. It has become a tourist destination for the } \\
\text { relaxing soak activities }\end{array}$ & 81.33 & High \\
\hline 2 & Anoa Sanctuary & $\begin{array}{l}\text { Built as semi-natural cage in Lejja recreation park for } \\
\text { preserving the endemic Sulawesi animals }\end{array}$ & 0.00 & Moderate \\
\hline 3 & Lejja view & Portraying the natural scenery of the Bulue landscape & 129.33 & High \\
\hline 4 & Camping ground & $\begin{array}{l}\text { Providing an attractive of natural scenery and potential } \\
\text { space for the camping area }\end{array}$ & 51.78 & High \\
\hline 5 & Datae hot spring & $\begin{array}{l}\text { Potential for warm water recreation which is located } \\
\text { near the river flows, mixed between warm water and } \\
\text { cold water }\end{array}$ & 71.22 & High \\
\hline 6 & Menawoe waterfall & $\begin{array}{l}\text { Portraying waterfalls with a total height of } \pm 10 \mathrm{~m} \text { in a } \\
\text { relatively remote area }\end{array}$ & 184.44 & High \\
\hline 7 & $\begin{array}{l}\text { Lapaserengi } \\
\text { waterfall }\end{array}$ & $\begin{array}{l}\text { One level waterfalls with a height of } \pm 5 \mathrm{~m} \text { located near } \\
\text { Datae }\end{array}$ & 143.00 & High \\
\hline 8 & Batumurue waterfall & $\begin{array}{l}\text { One level waterfalls with a height of } \pm 15 \mathrm{~m} \text { located near } \\
\text { Datae }\end{array}$ & 127.89 & High \\
\hline 9 & $\begin{array}{l}\text { Waepuange } \\
\text { waterfall }\end{array}$ & $\begin{array}{l}\text { Showing one level waterfalls with a height of } \pm 25 \mathrm{~m} \\
\text { located in a remote area }\end{array}$ & 122.11 & High \\
\hline 10 & $\begin{array}{l}\text { Sarasa-tandre } \\
\text { waterfall }\end{array}$ & $\begin{array}{l}\text { A stratified waterfall with a total height of } \pm 15 \mathrm{~m} \\
\text { located near Gellenge }\end{array}$ & 147.44 & High \\
\hline
\end{tabular}

The community of Bulue Village is divided into 9 settlements (Mario, Galungkalunge, Lejja, Datae, Gellenge, Kajuara, Poro, Lamatanruk and Wawogalunge). They are agricultural society, as seen as the pattern of the settlement located near to the river and rice fields. Meanwhile, the protected forest area, which is upstream of the river that flows into Datae and Gellenge, has been degraded.

The source of living in the community is dominated by farming. They need the extensification of farming for mixed plantation. 
The extensification of farming has caused landscape fragmentation. Landscape fragmentation will change a small portion of native habitat into a new habitat, which triggers the process of emigration and immigration of plant and animal species [7].

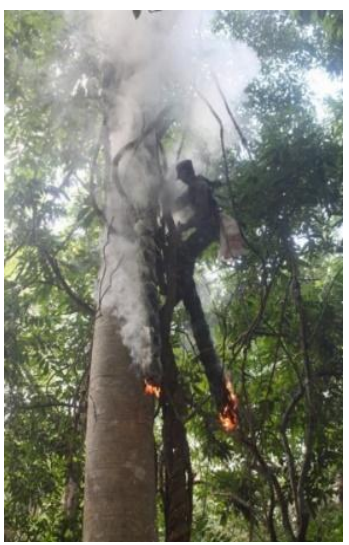

A. Taking honey in a tree

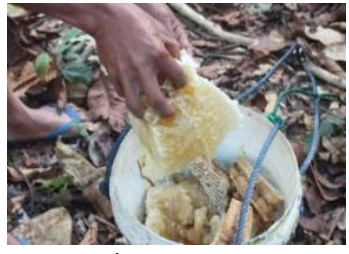

C. Fresh Honey

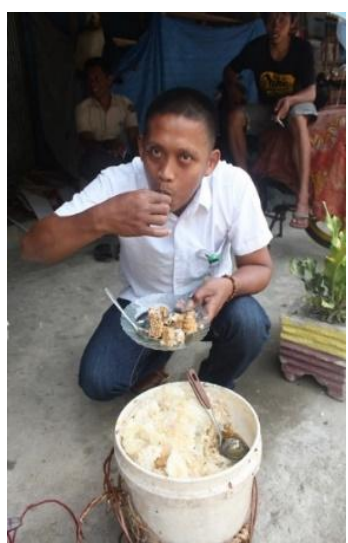

B. Eating the beehive mixed with fresh honey

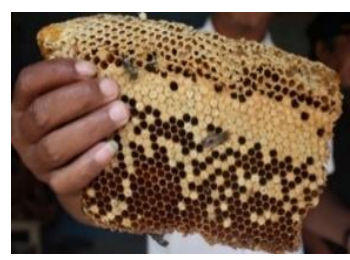

D. Beehive containing eggs and larvae
Figure 4. Forest Honey Harvesting

Based on research in the protected forest of Sinjai district, it was shown that the community encroached the forest because they did not know that the area is a protected forest area [14]. It caused by rare or unclear boundary signs of the protected forest area. The disturbance to protected forest areas has increased the level of turbidity, dissolved sediment, and nitrate content, especially in the rainy season [15]. Disturbance in the form of illegal logging and the conversion of part of the forest area into mixed fields do not significantly affect the decline in river water quality.

However, gold mining, settlement, and agriculture activities in the form of rice fields cause a significant decline in river water quality. The total percentage of the land cover of the Bulue landscape in the form of mixed plantations, settlements, rice fields, and rainfed fields is $17 \%$. Also, there is a high fluctuation in river flows between rainy season and dry season. Thus it can be said that land use activities in the Bulue landscape, more or less, affect habitat changes in the upstream and water quality in the downstream, especially in the rainy season.
The livelihoods of Bulue's people are mostly dependent on nature. Also, the lack of electricity has encouraged the community to use river flows for micro hydropower plants. However, landscape fragmentation has caused a high fluctuation in river flows. Life dependence on nature has the potential to create strong bonds. Thus, it can be used as social capital to include the community in maintaining the preservation of natural resources.

\section{Scenic Beauty of The Nature-based Tourism Attractions}

The results of the tourist's assessment have been obtained the beauty value of each attraction (Table 1). Calculations using the tabulated data show that Anoa sanctuary has an average value of $z=-0.17$ (closest to 0 ), so it used as standard value in calculating the SBE. There is only Anoa sanctuary that has a moderate value of scenic beauty. Meanwhile, the other attractions have a high value of scenic beauty. Natural landscape tends to have a high value of SBE [16]. The high value of SBE can be the driving factor in developing ecotourism.

The existence of Lejja hot springs in the Lejja Recreation Park as a leading tourist destination in Soppeng District certainly provides a big opportunity for the ecotourism development of other nature-based tourism attractions in the surrounding area, such as Walanae Protected Forest. It is expected to combine with the livelihood-based tourism attraction of Bulue's people.

Nearly $85 \%$ of the Bulue Village area is a state forest with the function of protected areas. It makes Bulue Village suitable to be a conservation village. Conservation village is a conservation model approach that provides opportunities for people living around conservation areas to be actively involved in efforts to manage conservation areas [17]. Meanwhile, the purpose of establishing conservation village is more directed at efforts to improve the welfare of village communities in and around production forests, protected forests, and conservation forests through empowering local potentials as an effort to increase resilience and the ability of communities to become actors of protection, preservation, and sustainable use. To empower the local potentials, the community needs to be strengthened through the development of the ecotourism network, which is a modification of Village Ecotourism Network (Jaringan Ekowisata Desa - JED) developed in Bali. 
JED was formed to realize ecotourism programs based on the community and the environment and as a form of commitment from several community groups who want to determine their future, culture, and environment [18]. Bali is a major tourist destination in Indonesia. Its people have actively implemented Community-Based Ecotourism (CBE) as a reaction to mass tourism activities that not only bring economic growth but also lead to ecological and social costs. The CBE initiative began by forming Jaringan Ekowisata Desa (JED) in collaboration with Yayasan Wisnu and Yayasan Kehati to find a more sustainable approach to tourism through stronger ownership and minimization of negative ecological impacts [19].

To implement CBE in Bulue Village as a strategic approach in developing ecotourism certainly needs modification and adjustment under the characteristics of the landscape also the legal status of the village's area, which is mostly a state forest area in the form of protected forest and conservation forest. Furthermore, collaborating among stakeholders is fully needed through synchronization of the planning until field implementation.

\section{CONCLUSION}

The Bulue Village has the potential of naturebased and livelihood-based tourism attractions with the high value of SBE. There are ten spots of attractions highlighted in the study consisted of five waterfalls, two hot springs, one wildlife sanctuary, one nature scenery, and one camping ground. Nevertheless, there some issues that need to be considered, in particular, to prevent further forest degradation and to provide economic alternatives for the locals as well as to improve the management of the site.

\section{REFERENCES}

[1] Bunruamkaew, K., and Y. Murayama. 2011. Site suitability evaluation for ecotourism using GIS \& AHP: A case study of Surat Thani Province, Thailand. Procedia - Social and Behavioral Sciences 21, 269-278

[2] Kiper, T. 2013. Role of ecotourism in sustainable development. Advances in Landscape Architecture, INTECH, 774-802.

[3] Ecotourism.org. 2019. What is ecotourism? Available at: https://ecotourism.org/whatis-ecotourism/.

[4] Drumm, A., and A. Moore. 2005. Ecotourism development - a manual for conservation planners and managers Volume I: An Introduction to ecotourism planning, $2^{\text {nd }}$
Ed. The Nature Conservancy Worldwide. Arlington, Virginia, USA.

[5] Fandeli, C., and Muhammad. 2009. Prinsipprinsip dasar mengkonservasi lanskap, $1^{\text {st }}$ Ed. Gadjah Mada University Press. Yogyakarta.

[6] Janic, M., and P. Sestras. 2019. Identification and evaluation of landscape as a precondition for planning revitalization and development of mediterranean rural settlements - case study: Mrkovi Village, Bay of Kotor, Montenegro. Sustainability 11(2039), 1-15.

[7] Prasetyo, L. B. 2017. Pendekatan Ekologi lanskap untuk konservasi biodiversitas. Faculty of Forestry, Bogor Agriculturl University. Bogor.

[8] Statistic Center of Soppeng Regency. 2018. Kecamatan Marioriawa in numbers. Statistic Center, Soppeng Regency. Watansoppeng.

[9] Marjuki, B. 2016. Pendangkalan Danau Tempe Sulawesi Selatan (1981 - 2015) dan upaya konservasi sumber daya air. Ministry of Public Works and Housing, Republic of Indonesia. Jakarta.

[10] Forestry Sevice, South Sulawesi Province. 2018. Rencana Pengelolaan Hutan Jangka Panjang (RPHJP) KPHL Unit XII Walanae Periode 2019 - 2028. Forestry Sevice, South Sulawesi Province. Soppeng.

[11] Rahayuningsih, T., E. K. S. H. Muntasib, and L. Budi. 2016. Nature based tourism resources assessment using Geographic Information System (GIS): case study in Bogor. Procedia Environmetal Sciences 33, 365-375.

[12] Daniel, T., and R. Boster. 1976. Measuring landscape esthetic: the scenic beauty estimation method. USDA Forest Service U.S Department of Agricultural. US.

[13] Local Company of Soppeng Regency. 2019. Rencana pengusahaan pariwisata alam Perusda Kabupaten Soppeng - di ruang usaha dari Blok Pemanfaatan TWA Lejja, Kabupaten Soppeng, Provinsi Sulawesi Selatan jangka waktu tahun 2020 s/d 2075. Local Company of Soppeng Regency.

[14] Wahid, A. M. Y., N. Bohari, and Achmad. 2015. The environmental law enforcement in forestry sector (study on the protected forest in Sinjai Region, South Sulawesi). Hasanuddin Law Review 1(1), 61-73.

[15] Supangat, A. B. 2013. Effects of disturbances of protected forest area on river water quality: case study at Jambi 
Province. Indonesian Forest Rehabilitation Journal 1, 75-89.

[16] Wakyudi. 2016. Perencanaan lanskap ekowisata di daerah penyangga kawasan konservasi Taman Nasional Ujung Kulon Provinsi Banten. Bogor Agricultural University. Bogor.

[17] Nugroho, S. S., and N. D. Setyowati. 2014. Model pengembangan desa konservasi berbasis pendayagunaan potensi lokal Kawasan Lindung Lereng Gunung Wilis Kabupaten Madiun Jawa Timur. Sosial 15, , 54-62.

[18] Saragih, W. R. J., I. M. Sendra, and I. G. S. Mananda. 2015. Karakteristik dan motivasi wisatawan ekowisata di Bali 9 studi kasus di jaringan ekowisata desa. Jurnal Industri Perjalanan Wisata 3(1), 17-21.

[19] Byczek, C. 2011. Blessings for all ? Community-Based Ecotourism in Bali Between Global, National, and Local Interests - A Case Study. Austrian Journal of South-East Asian Studies 4(1), 81-106. 